BMC

Complementary \& Alternative Medicine

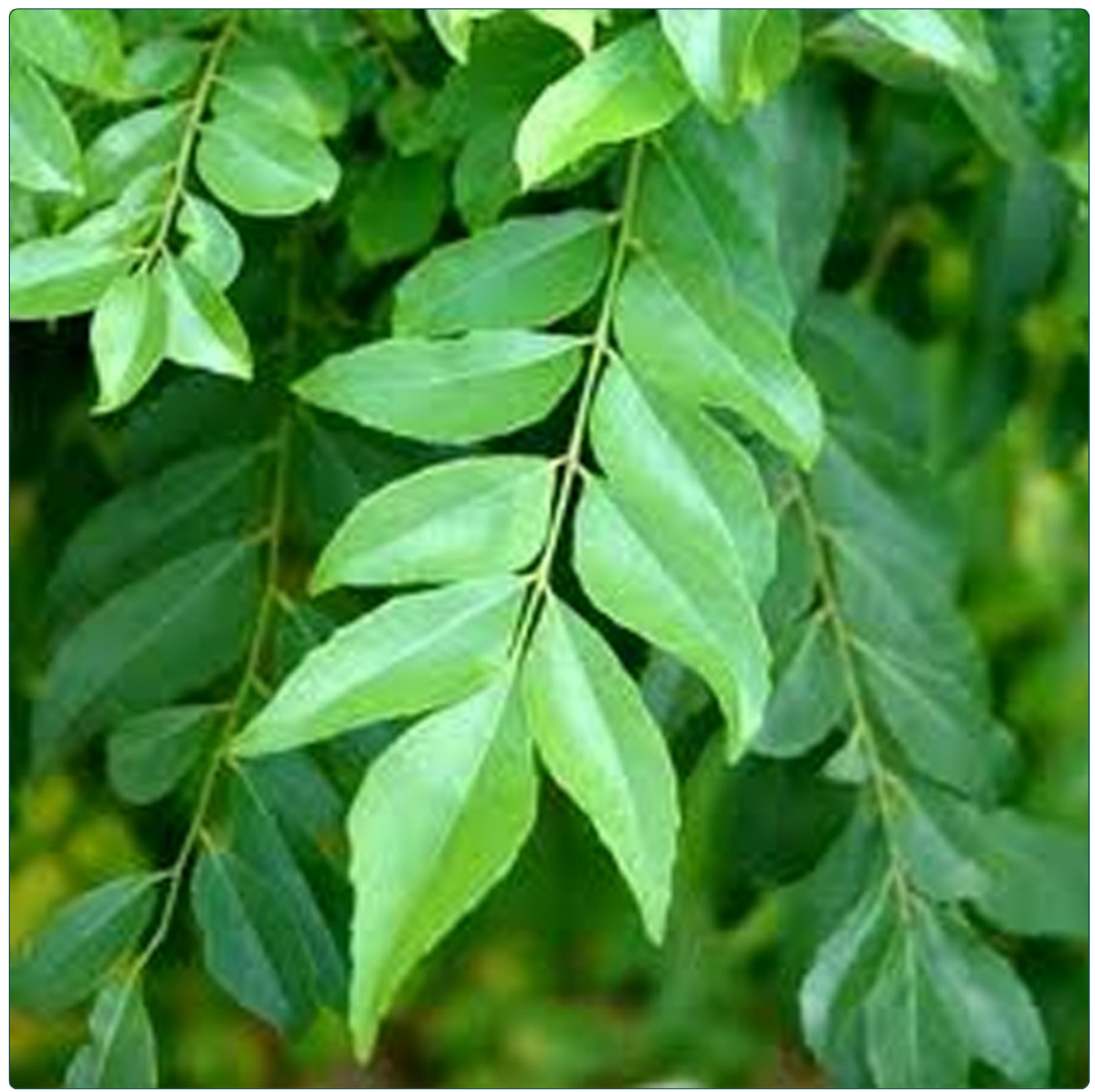

Murraya koenigii leaf extract inhibits proteasome activity and induces cell death in breast cancer cells

Noolu et al. 


\title{
Murraya koenigii leaf extract inhibits proteasome activity and induces cell death in breast cancer cells
}

\author{
Bindu Noolu', Rajanna Ajumeera², Anitha Chauhan ${ }^{1}$, Balakrishna Nagalla ${ }^{3}$, Raghunath Manchala ${ }^{1}$
} and Ayesha Ismail ${ }^{*}$

\begin{abstract}
Background: Inhibition of the proteolytic activity of 265 proteasome, the protein-degrading machine, is now considered a novel and promising approach for cancer therapy. Interestingly, proteasome inhibitors have been demonstrated to selectively kill cancer cells and also enhance the sensitivity of tumor cells to chemotherapeutic agents. Recently, polyphenols/flavonoids have been reported to inhibit proteasome activity. Murraya koenigii Spreng, a medicinally important herb of Indian origin, has been used for centuries in the Ayurvedic system of medicine. Here we show that Murraya koenigii leaves (curry leaves), a rich source of polyphenols, inhibit the proteolytic activity of the cancer cell proteasome, and cause cell death.

Methods: Hydro-methanolic extract of curry leaves (CLE) was prepared and its total phenolic content [TPC] determined by, the Folin-Ciocalteau's method. Two human breast carcinoma cell lines: MCF-7 and MDA-MB-231 and a normal human lung fibroblast cell line, WI-38 were used for the studies. Cytotoxicity of the CLE was assessed by the MTT assay. We studied the effect of CLE on growth kinetics using colony formation assay. Growth arrest was assessed by cell cycle analysis and apoptosis by Annexin-V binding using flow cytometry. Inhibition of the endogenous 265 proteasome was studied in intact cells and cell extracts using substrates specific to 205 proteasomal enzymes.
\end{abstract}

Results: CLE decreased cell viability and altered the growth kinetics in both the breast cancer cell lines in a dose-dependent manner. It showed a significant arrest of cells in the $\mathrm{S}$ phase albeit in cancer cells only. Annexin $\mathrm{V}$ binding data suggests that cell death was via the apoptotic pathway in both the cancer cell lines. CLE treatment significantly decreased the activity of the 265 proteasome in the cancer but not normal cells.

Conclusions: Our study suggests M. koenigii leaves to be a potent source of proteasome inhibitors that lead to cancer cell death. Therefore, identification of active component(s) from the leaf extract could lead to the development of anti-cancer agents which could be useful in the treatment of different types of cancers.

Keywords: Murraya koenigii, 265 proteasome, Breast cancer, Polyphenols, Methanolic extract, Proteasome inhibitor

\footnotetext{
*Correspondence: ayeshai2005@gmail.com

'Department of Endocrinology \& Metabolism, National Institute of Nutrition, Hyderabad, India

Full list of author information is available at the end of the article
} 


\section{Background}

Breast cancer is the second most prevalent cancer in the world next only to lung cancer [1] and is a major public health problem in developing countries like India. Every year 75,000 new cases of breast cancer are reported in India. The increase in the number of cases has been attributed to factors such as genetics, environmental pollution, urbanization and changing food habits.

Murraya koenigii Spreng (curry-leaf tree), is a small aromatic tree belonging to the family Rutaceae. It is a tropical to sub-tropical tree native to India. Of the 14 global species belonging to the genus Murraya, only two are available in India, namely, M. koenigii and M. paniculata. Of the two M. koenigii is more popular due to its large spectrum of medicinal properties. M. koenigii leaves have a slightly pungent, bitter and feebly acidulous taste and these characteristics are retained even after drying. Fresh and dried curry leaves are extensively used in South Indian culinary practices for seasoning and flavouring dishes [2]. Different parts of the plant such as leaves, root, bark and fruit are known to possess various biological activities. Traditionally, this plant is used in Indian systems of medicine for a variety of ailments and also used as a tonic, stomachic, and carminative [3-5].

The major chemical constituents of the plant reported are carbazole alkaloids, coumarins and flavonoids [6]. M. koenigii leaf extracts exhibit hypoglycemic and hypolipidemic effects in experimental animals [7-9]. Carbazole alkaloids and methanolic extracts of M. koenigii are also reported to possess anti-oxidative [10-12], anti-diarrheal and anti-trichomonal activities [13,14]. M. koenigii leaf extracts reduced blood cholesterol and glucose levels in ob/ob mice [15]. Methanolic extract of M. koenigii leaves possess anti-inflammatory [16] and immunomodulatory activity [17]. Mahanine, a carbazole alkaloid purified from M. koenigii leaves has apoptotic effects in human leukemia cells [18-20].

We and others have shown that a hydro-methanolic extract of M. koenigii leaves is rich in phenolic content $[10,21]$. Polyphenols have a wide spectrum of biological
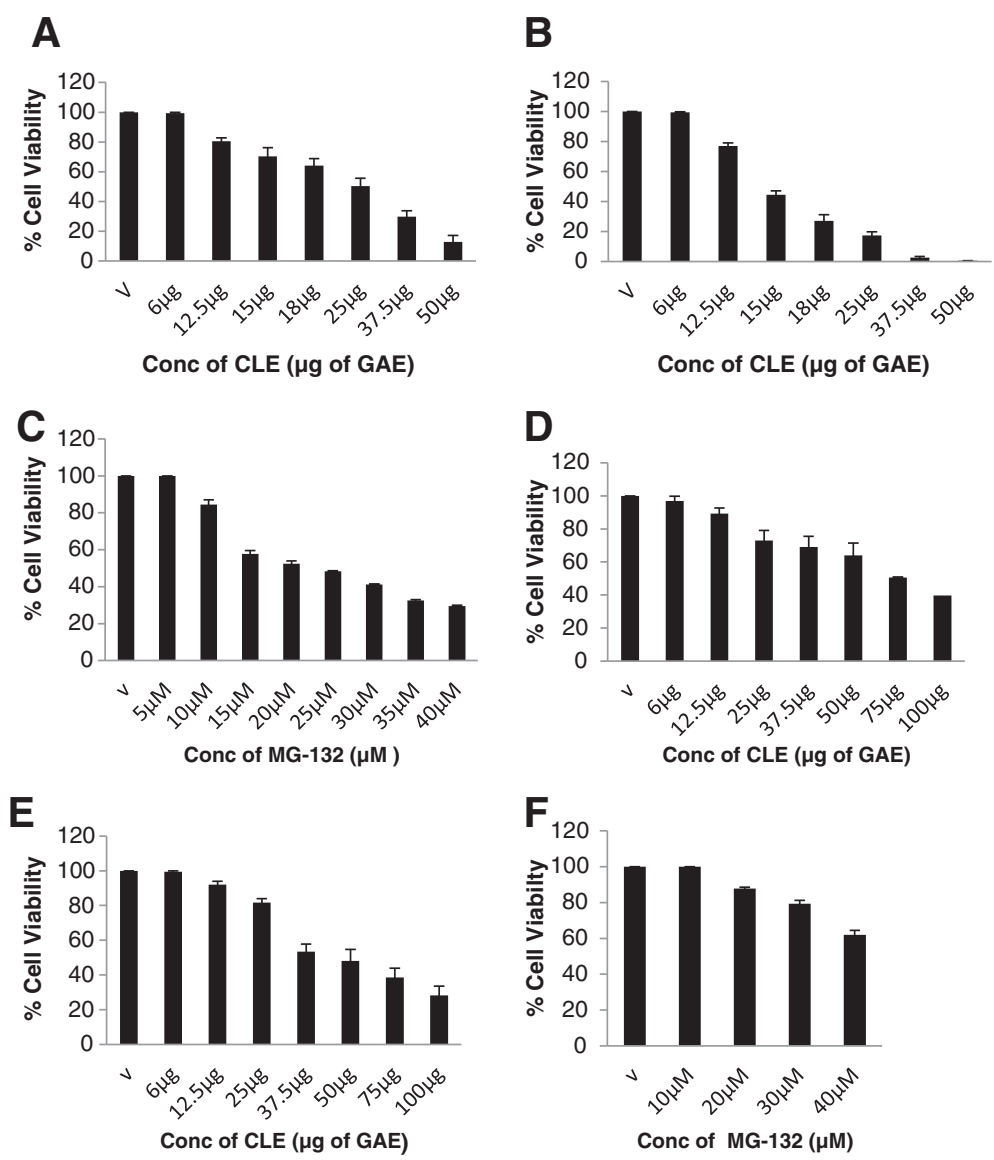

Figure 1 Curry leaf extract decreases cell viability of breast cancer cells: Panels A \& B shows results of MTT assay after 12 h and 24 h treatment with CLE, whereas Panel $\mathbf{C}$ shows results of MTT assay after $24 \mathrm{~h}$ treatment with MG-132, a specific proteasome inhibitor respectively in MDA-MB-231 cell line. Panels $\mathbf{D}$ \& $\mathbf{E}$ shows results of MTT assay after $12 \mathrm{~h}$ and $24 \mathrm{~h}$ treatment with CLE, whereas Panel $\mathbf{F}$ shows results of MTT assay after $24 \mathrm{~h}$ treatment with MG-132, in MCF-7 cell line. The data represents mean+/- SEM of three independent experiments. 


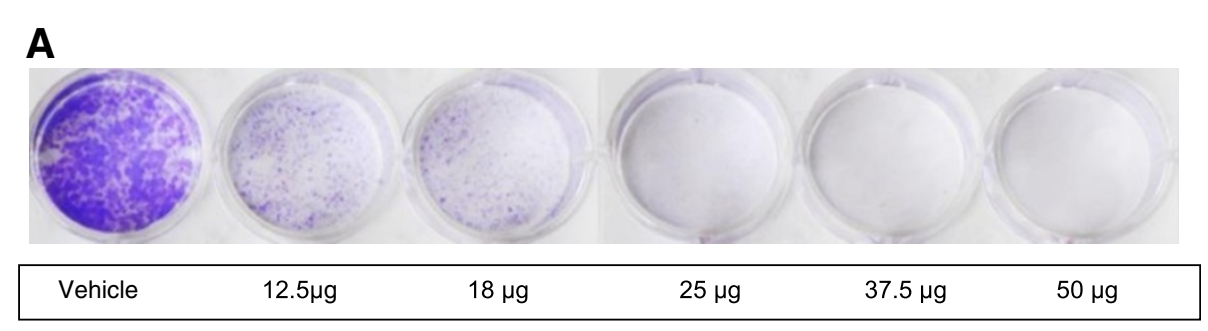

B

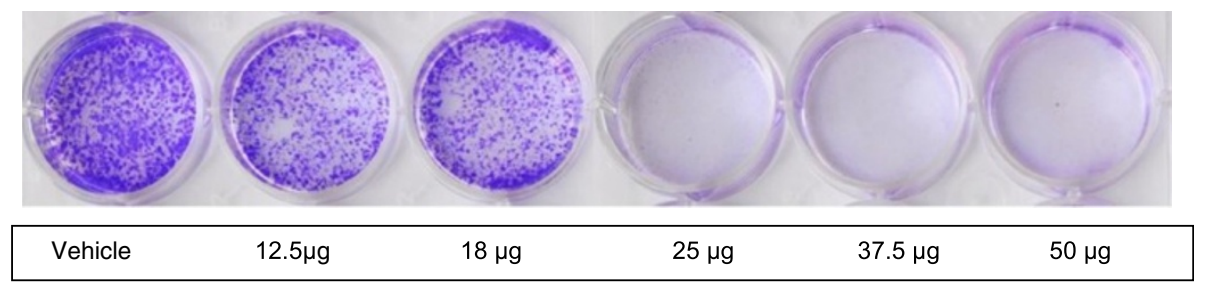

Figure 2 Curry leaf extract alters growth kinetics of breast cancer cells: Panel A depicts results of colony formation assay in MDA-MB-231 cell line. Panel $\mathbf{B}$ depicts results of colony formation assay in MCF-7 cell line. Cells were grown in 6-well plates and treated with various concentrations of the CLE (0-50 $\mu \mathrm{g}$ GAE). After a week cells were stained with crystal violet and photographed.

activities, including anti-oxidant, anti-inflammatory and metal-chelating properties [22,23]. Recent studies have shown that naturally occurring polyphenols/flavanoids modulate the functionality of the $26 \mathrm{~S}$ proteasome, a multienzymatic, multi-catalytic complex localized both in the cytoplasm and nucleus of eukaryotic cells [24,25]. The $26 \mathrm{~S}$ proteasome is a huge 2.4 MDa complex comprising of two sub-complexes - the 19S regulatory subunit and the $20 \mathrm{~S}$ catalytic subunit [26]. The $20 \mathrm{~S}$ sub-unit possesses at least three distinct activities, which are associated with the three different $\beta$ subunits respectively: chymotrypsin-like activity $(\beta 5)$, trypsin-like activity $(\beta 2)$ and the caspase-like activity ( $\beta 1$ ) [27]. The $26 \mathrm{~S}$ proteasome is the major non-lysosomal pathway of protein degradation in eukaryotic cells. This proteolytic machine is involved in the degradation of oxidized, unfolded and misfolded proteins and antigen presentation [28-31]. It regulates several cellular processes such as apoptosis, signal transduction, cell-cycle regulation and cell differentiation [32]. Two important functions of the proteasome system are to promote tumor cell proliferation and protect tumor cells against apoptosis $[27,33,34]$.

In the present work, we demonstrate for the first time that the hydro-methanolic extract of M. koenigii leaves rich in phenolic content, potently inhibits the activity of the proteasome both in vitro and in vivo. The CLE induced cell death in two breast cancer cell lines in a time and dosedependent manner. The leaf extract altered the growth kinetics of the cancer cells in a dose-dependent manner as demonstrated by the colony formation assay. Cancer cells but not normal cells were arrested in the $S$ phase of the cell cycle. Annexin V binding experiments demonstrate that apoptosis was induced by CLE in both the breast carcinoma cell lines.

\section{Methods \\ Chemicals \& reagents}

Dulbecco's Modified Eagle's Medium (DMEM)- cell culture media, antibiotic-antimycotic mix, sodium pyruvate, nonessential amino acid mix and stable glutamine were purchased from Himedia (Mumbai, India); fetal bovine serum (FBS) was purchased from (GIBCO, Invitrogen USA), 3-[4, 5-dimethyltiazol-2-yl]-2.5-diphenyl-tetrazolium bromide (MTT), Dimethylsulfoxide (DMSO), Propidium Iodide, Ribonuclease A, Dithiothreitol (DTT), 3-[(3-Cholamidopropyl)dimethylammonio]-1-propanesulfonate (CHAPS), Ethylene diamine tetra acetic acid (EDTA), Phenyl methyl sulfoxide (PMSF), Crystal-violet, Sodium dodecyl sulphate (SDS) and 4-(2-Hydroxyethyl) piperazine-1-ethanesulfonic acid N-(2-Hydroxyethyl)piperazine- $\mathrm{N}^{\prime}$-(2-ethanesulfonic acid) (HEPES) were purchased from Sigma-Aldrich (St Louis, MO, USA). The fluorogenic proteasomal peptide substrates Suc-LLVYAMC (chymotrypsin-like substrate), BOC-Leu-Arg-ArgAMC (trypsin -like substrate) and Z-Leu-Leu-Glu-AMC (caspase- like substrate) and MG-132 (carbobenzoxy-LeuLeu-leucinal - a specific inhibitor of the 26S proteasome) were procured from ENZO Life sciences, USA. 20S rabbit proteasome was purchased from Boston Biochem, USA. All other reagents were procured from Qualigens fine chemicals (Mumbai, India). Annexin staining was done using a kit (Annexin V-FITC Apoptosis detection kit; BD Pharmingen, San Jose, CA, USA). 


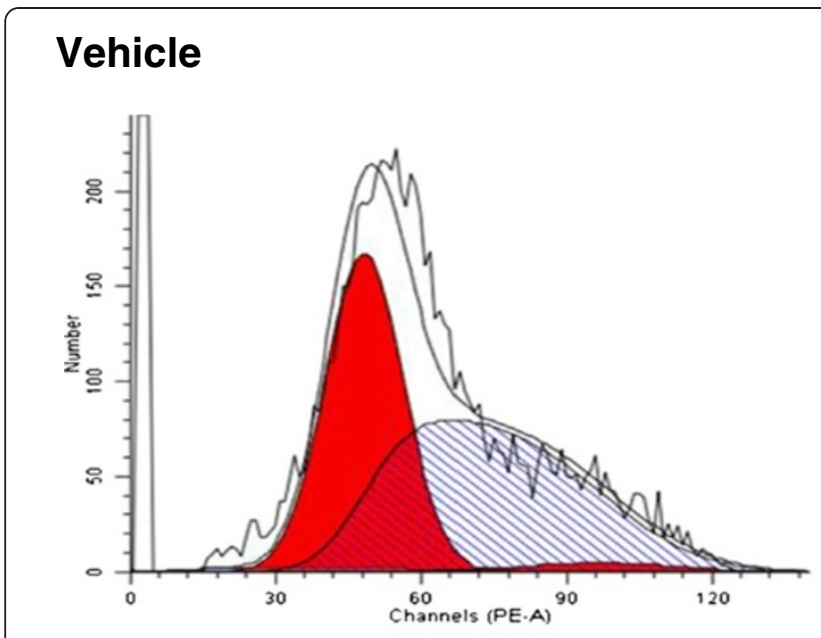

\section{$6 \mu g$ CLE}

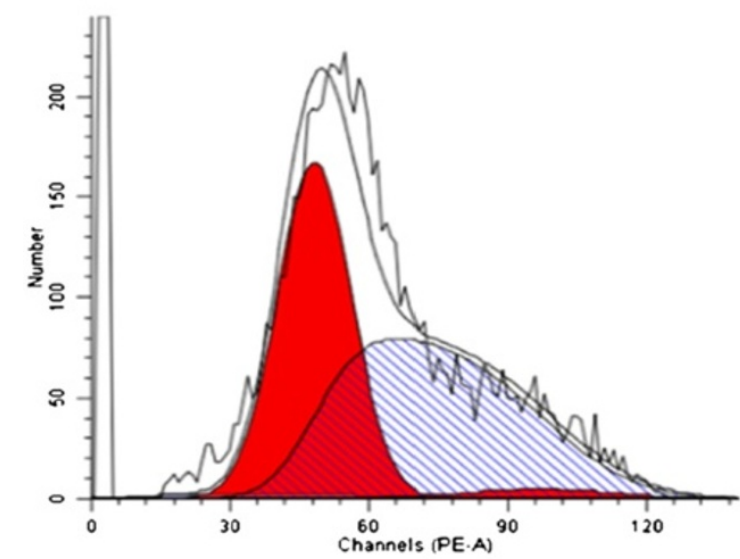

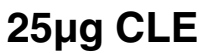

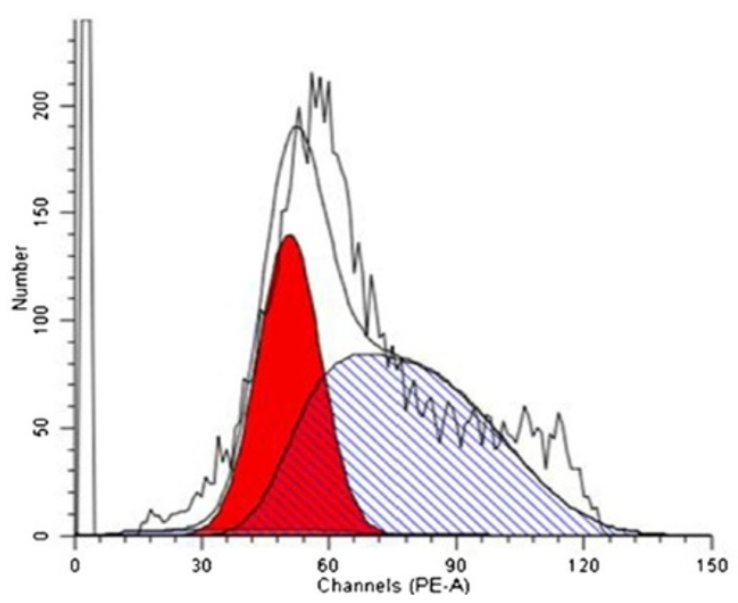

\section{3rg CLE}

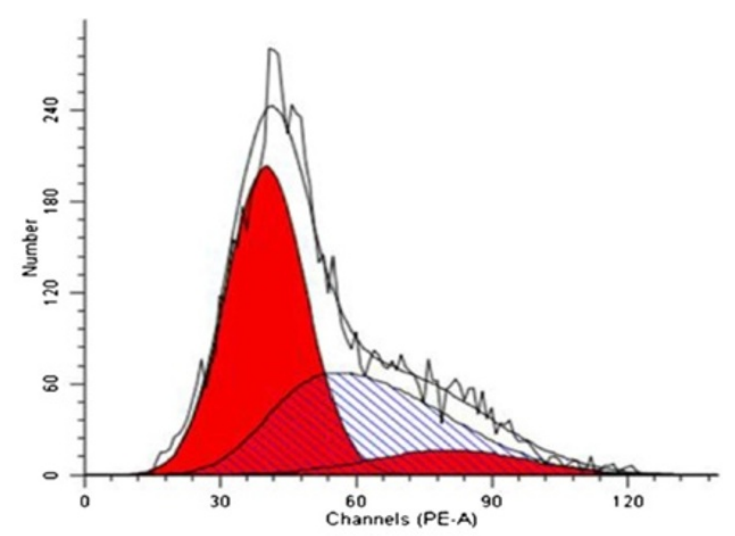

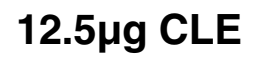

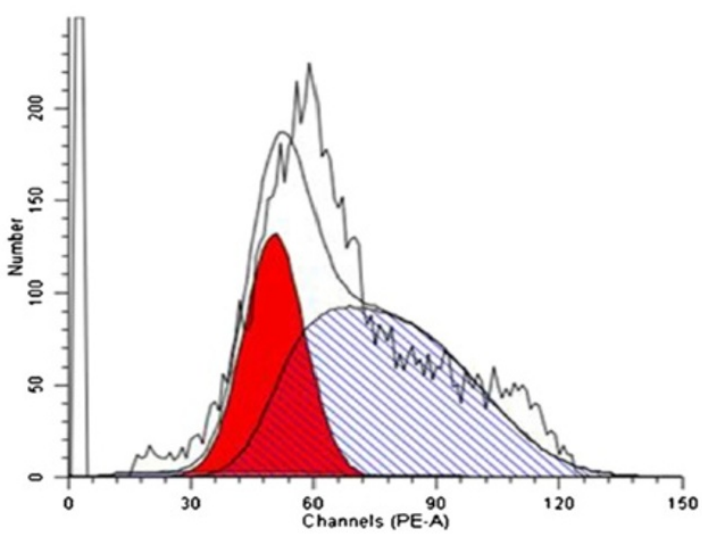

Figure 3 Cell cycle arrest by CLE in the MDA-MB-231 breast carcinoma cell line. Cell cycle analysis of MDA-MB-231 cells treated with varying concentrations of CLE for $24 \mathrm{~h}$ was done by flow cytometry. 


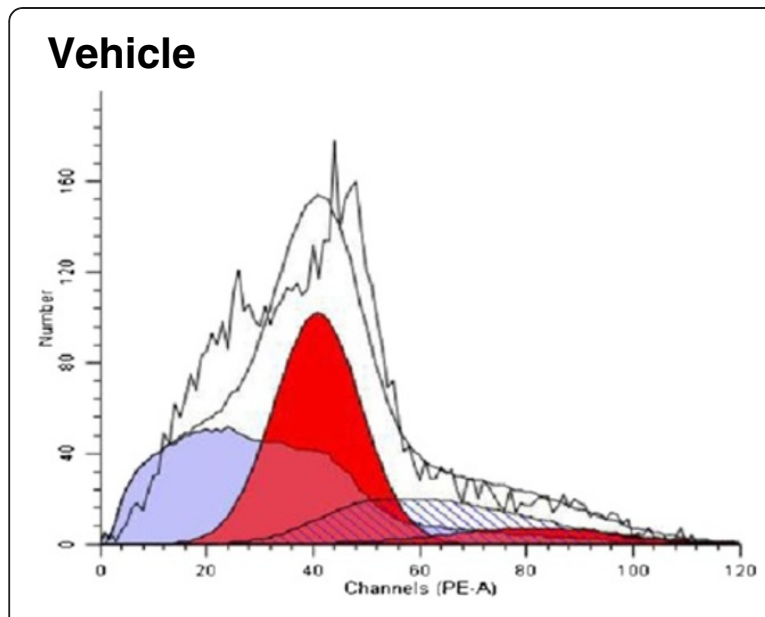

\section{5ug CLE}

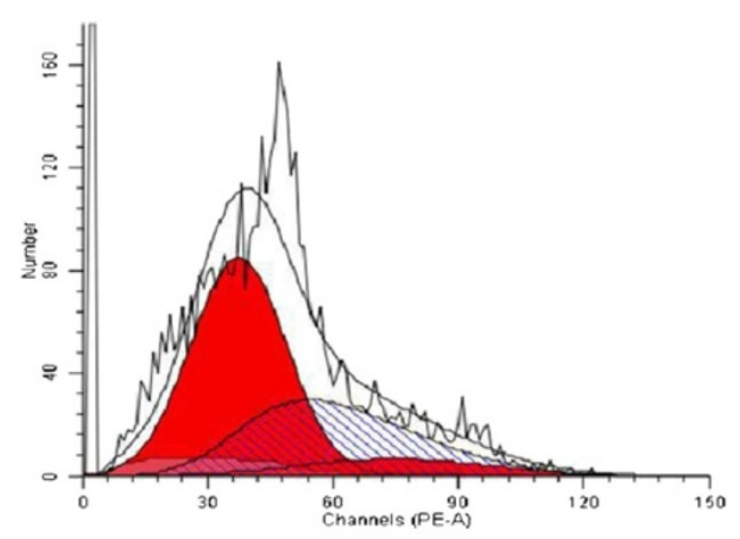

\section{0ug CLE}

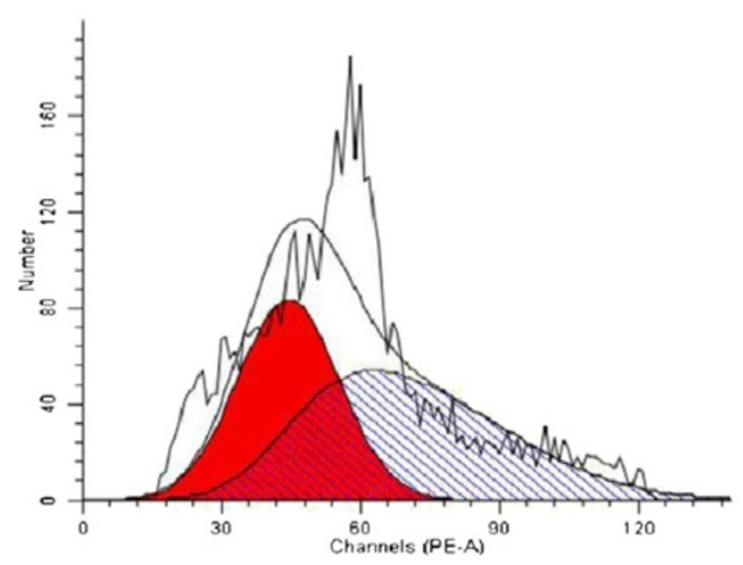

\section{5ug CLE}

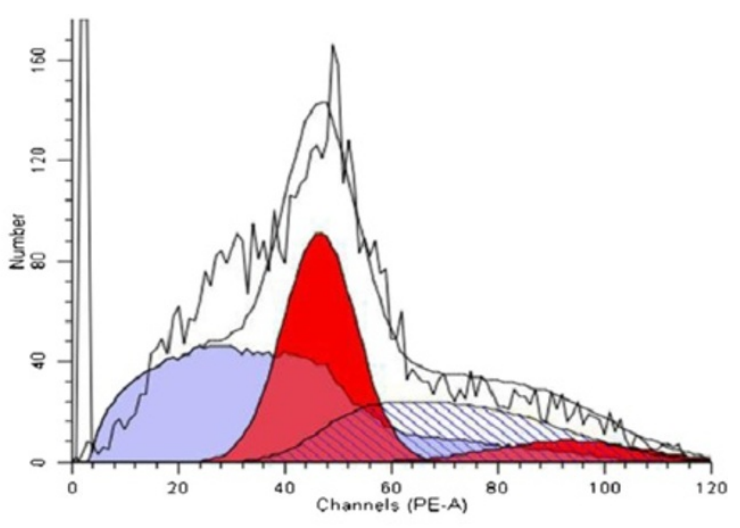

37.5ug CLE

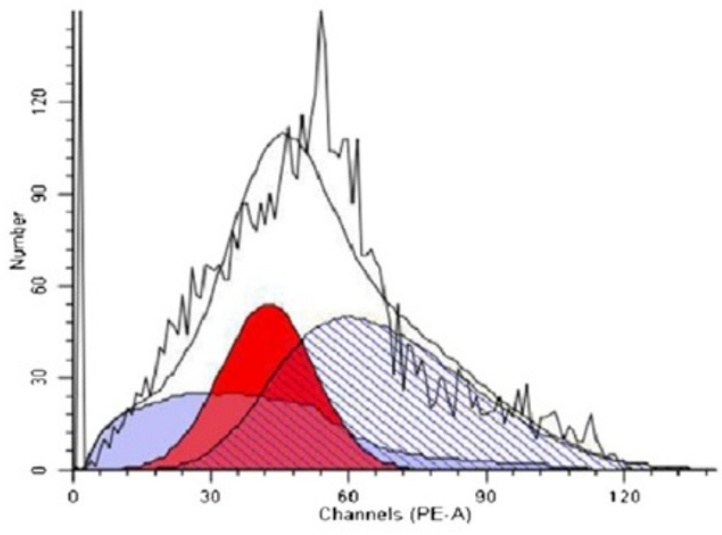

Figure 4 Cell cycle arrest by CLE in the MCF-7 breast carcinoma cell line. Cell cycle analysis of MCF-7 cells treated with varying concentrations of CLE for $24 \mathrm{~h}$ was done by flow cytometry. 
Table 1 Distribution [\%] of MDA-MB-231 cells in different phases of the cell cycle

\begin{tabular}{lccccc}
\hline CELL PHASE & VEHICLE & $3 \mu \mathrm{g}$ & $6 \mu \mathrm{g}$ & $12.5 \mu \mathrm{g}$ & $25 \mu \mathrm{g}$ \\
\hline G0-G1 & 43.98 & 54.15 & 44.53 & 33.9 & 37.3 \\
\hline S & 52.07 & 37.26 & 53 & 66.10 & 62.6 \\
\hline G2-M & 3.95 & 8.59 & 2.48 & 0.0 & 0.0 \\
\hline
\end{tabular}

\section{Preparation of curry leaf extracts}

Curry leaves were collected from the local area from a single tree. Identity of the curry leaves was confirmed by Dr. B. Pratibha Devi, Professor and Head, Department of Botany, Osmania University, Hyderabad, India. A voucher specimen (voucher no: 068) was deposited in a herbarium at the Department of Botany, Osmania University, Hyderabad, India. The leaves were washed and air dried in shade for 3 weeks. After drying, the leaves were ground to a fine powder using an electric mixer grinder. The leaf powder was extracted with $80 \%$ methanol in water by keeping on a vortex mixer for 3-4days. This was followed by centrifugation of the extract at $5000 \mathrm{rpm}$ for $30 \mathrm{~min}$. The supernatant was filtered using a $0.4 \mu \mathrm{m}$ filter (Millipore). The resultant Methanol: Water extract was stored at $-20^{\circ} \mathrm{C}$ and was used for all our studies. These extracts designated as 'CLE', were used in the cell-culture assays at different doses based on their total phenolic content [equivalent to $\mu \mathrm{g}$ of gallic acid (GAE)] measured spectrophotometrically by the Folin-Ciocalteau method.

\section{Total Phenolic Content (TPC)}

The total phenolic content of the extract was determined with Folin-Ciocalteau's reagent using Gallic acid as a standard [35]. Different concentrations of Gallic acid standards $(20-100 \mu \mathrm{g} / \mu \mathrm{l})$ and CLE samples were taken in glass test tubes and volume was made up to $150 \mu \mathrm{l}$ with distilled water. $750 \mu \mathrm{l}$ of $10 \%$ Folin's reagent was added and kept for 5 minutes at room temperature, followed by addition of $750 \mu \mathrm{l}$ of $6 \% \mathrm{Na}_{2} \mathrm{CO}_{3}$ and vortexed for 5 minutes. The tubes were then incubated for 90 minutes at room temperature. The absorbance was measured at $725 \mathrm{~nm}$ in a Hitachi double beam spectrophotometer. The final concentration of the total polyphenols present in the extract was expressed as $\mu \mathrm{g}$ of Gallic Acid Equivalents (GAEs).

Table 2 Distribution [\%] of MCF-7 cells in different phases of the cell cycle

\begin{tabular}{lccccc}
\hline CELL PHASE & VEHICLE & $12.5 \mu \mathrm{g}$ & $25 \mu \mathrm{g}$ & $37.5 \mu \mathrm{g}$ & $50 \mu \mathrm{g}$ \\
\hline G0-G1 & 63.51 & 52.24 & 56.42 & 35.62 & 44.46 \\
\hline $\mathrm{S}$ & 27.89 & 38.22 & 34.68 & 64.38 & 55.54 \\
\hline G2-M & 8.60 & 9.59 & 8.89 & 0.0 & 0.0 \\
\hline
\end{tabular}

\section{Cell lines}

MCF-7 and MDA-MB-231 (breast carcinoma cell lines) and WI-38 (normal human lung fibroblasts) were obtained from the National Centre for Cell Sciences, Pune, India. Cells were maintained in DMEM supplemented with $10 \%$ FBS, $2 \mathrm{mM}$ Higluta-XL, 100 units/ml penicillin, $100 \mu \mathrm{g} / \mathrm{ml}$ streptomycin and $0.5 \mathrm{ng} / \mathrm{ml}$ amphotericin B, $1 \mathrm{mM}$ sodium pyruvate and $1 \mathrm{X}$ non-essential amino acid mixture. Cells were maintained and grown in a humidified atmosphere at $37^{\circ} \mathrm{C}$ and $5 \% \mathrm{CO}_{2}$. WI-38 cells were grown for no more than 30 passages, as recommended by European Collection of Cell Cultures (ECACC).

\section{Cell viability/proliferation assay}

Cell viability was determined by quantification of 3-(4,5dimethylthiazol-2-yl)-2,5-di-phenyltetrazolium bromide (MTT) reduction by mitochondrial dehydrogenases. In brief, $1 \times 10^{5}$ cells/well were plated in a 96-well plate and incubated with different concentrations of the CLE for either $12 \mathrm{~h}$ or $24 \mathrm{~h}$ or with MG-132 for $24 \mathrm{~h}$. Following this, MTT was added to a final concentration of $100 \mu \mathrm{g} /$ well and further incubated for $3 \mathrm{~h}$ at $37^{\circ} \mathrm{C}$. The formazan dye crystals formed were solubilized in DMSO and the plate was incubated at room temperature for $1 \mathrm{~h}$. The absorbance was measured at $595 \mathrm{~nm}$ in an ELISA microplate reader (Biotek, New York, USA). All samples were assayed in triplicate in three independent experiments. Absorbance values plotted are the mean from three independent experiments and the results are expressed as percentage of the control, which was considered to be $100 \%$.

\section{Colony formation assay}

MCF-7 and MDA-MB-231 cells were plated in duplicate at a density of $1 \times 10^{4}$ and $1 \times 10^{3}$ cells $/ \mathrm{ml}$ respectively in 6-well plates. Next day, the cells were treated with varying concentrations of CLE. Plates were incubated at $37^{\circ} \mathrm{C}$ and $5 \% \mathrm{CO}_{2}$ for one week. After a week, the colonies were fixed with $4 \%$ formaldehyde for $15 \mathrm{mins}$ followed by staining with $0.005 \%$ crystal violet. The colonies were photographed with a digital Nikon D90 camera. Three independent experiments were done with each cell line.

\section{Cell cycle analysis and annexin $\mathrm{V}$ binding assay}

Cell cycle analysis: MCF-7 or MDA-MB-231 or WI-38 cells were plated at a density of $1.5 \times 10^{6}$ cells in a $10 \mathrm{~cm}$ dish. Next day, cells were treated with different doses of the CLE. After $24 \mathrm{~h}$ incubation, cells were harvested and suspended in 1X-PBS containing $2 \%$ FBS. The cells were fixed with $70 \%$ ethanol at $4^{\circ} \mathrm{C}$ for $1 \mathrm{~h}$ followed by the addition of propidium iodide $(5 \mu \mathrm{g} / \mu \mathrm{l})$ and RNase $(10 \mu \mathrm{g} /$ $\mu \mathrm{l})$ and further incubated for $3 \mathrm{~h}$ at $4^{\circ} \mathrm{C}$. The DNA content was evaluated in a flow cytometer (BD FACS ARIAII, 


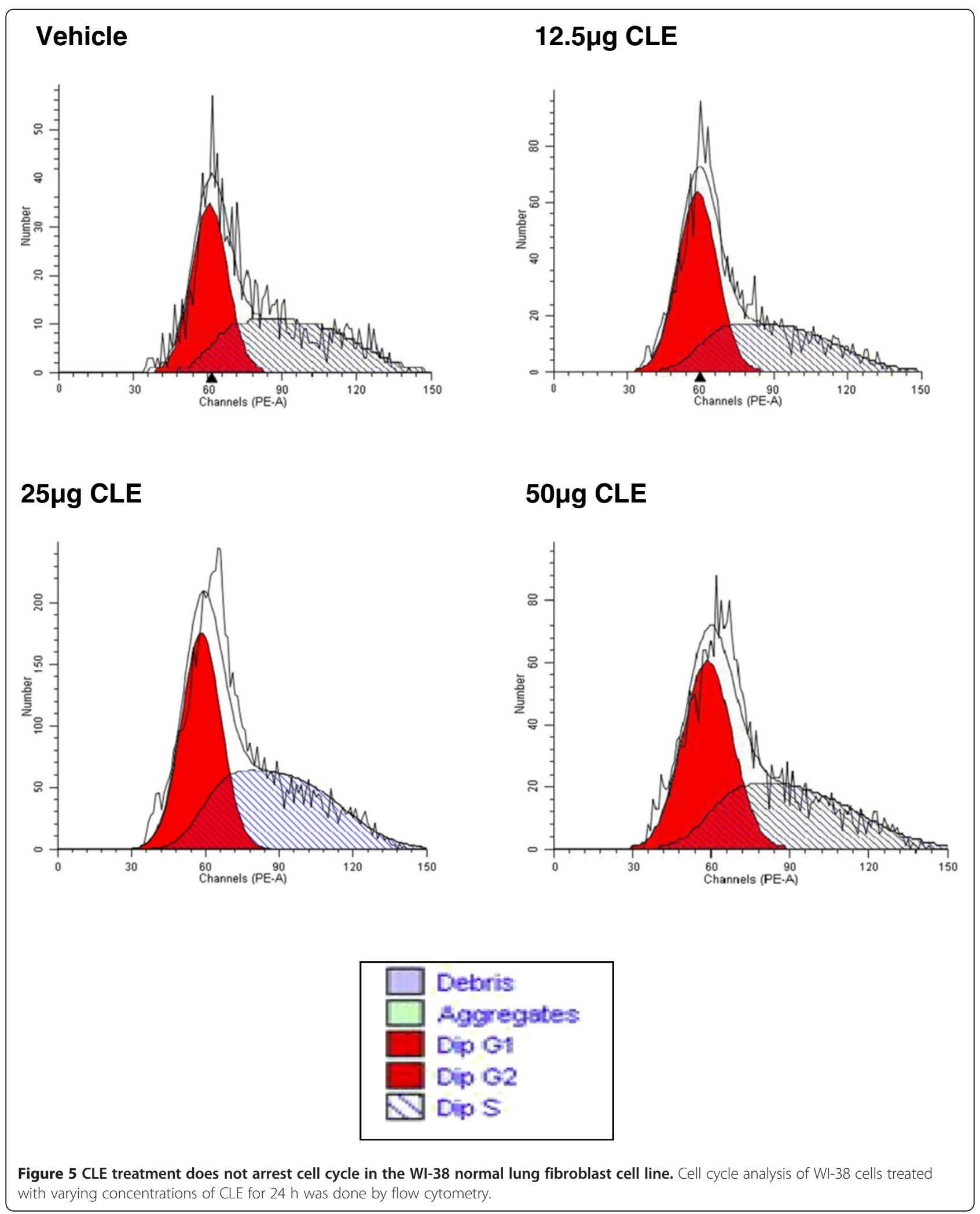


Table 3 Distribution [\%] of WI-38 cells in different phases of the cell cycle

\begin{tabular}{lcccc}
\hline CELL PHASE & VEHICLE & $12.5 \mu \mathrm{g}$ & $25 \mu \mathrm{g}$ & $50 \mu \mathrm{g}$ \\
\hline G0-G1 & 48.7 & 55.83 & 48.57 & 52.8 \\
\hline S & 50.35 & 44.16 & 51.43 & 47.20 \\
\hline G2-M & 0.87 & 0.00 & 0.00 & 0.00 \\
\hline
\end{tabular}

USA). The data was analyzed using Modfit software (BD Biosciences, USA).

Annexin-V staining: MCF-7 or MDA-MB-231 cells were plated at a density of $1.5 \times 10^{6}$ cells in a $10 \mathrm{~cm}$ dish. Next day, cells were treated with different doses of the CLE. After $24 \mathrm{~h}$ incubation, cells were washed with 1X-PBS and re-suspended in $100 \mu \mathrm{l}$ binding buffer (supplied by the vendor). Cells were stained with Annexin V-FITC and propidium iodide according to the manufacturer's protocol before analysis by flow cytometry.

\section{Inhibition of purified 20 S proteasome activity}

Chymotrypsin-like activity of the purified 20S proteasome was measured as follows: In brief, $200 \mathrm{ng}$ of purified $20 \mathrm{~S}$ proteasome was incubated in $200 \mu \mathrm{l}$ of assay buffer (50 mmol/L Tris- $\mathrm{HCl}, \mathrm{pH} 8.0$ containing $0.035 \%$ SDS) with or without different concentrations of CLE and $40 \mu \mathrm{M}$ substrate Suc-Leu-Leu-Val-Tyr-AMC (for chymotrypsinlike activity) and incubated for $2 \mathrm{~h}$ at $37^{\circ} \mathrm{C}$. The free 7amino-4-methylcoumarin (AMC) liberated was measured fluorimetrically using a multi-mode reader [Spectra Max M5] using an excitation filter $(380 \mathrm{~nm})$ and emission filter $(460 \mathrm{~nm})$. The data is plotted as mean $(+/-$ standard error) and is expressed as a percentage of the control, which was considered to be $100 \%$. The assay was repeated thrice.

\section{Inhibition of 265 proteasome activity in intact cells}

To measure inhibition of the proteasome activity in living tumor cells, MCF-7 or MDA-MB-231 or WI-38 cells were plated at a density of $1 \times 10^{4}$ in a 24 well plate. Next day, cells were treated with or without the CLE at the indicated concentrations. After $24 \mathrm{~h}$ of treatment, the media was aspirated out and $500 \mu \mathrm{l}$ of $1 \mathrm{X}-\mathrm{PBS}$ was added followed by addition of fluorogenic substrates (20 $\mu \mathrm{M}$ final concentration) specific for the chymotrypsinlike (Ch-L), trypsin-like (T-L) and caspase-like (Cp-L) activities of the $20 \mathrm{~S}$ proteasome. The plate was then incubated for $2 \mathrm{~h}$ at $37^{\circ} \mathrm{C} .200 \mu \mathrm{l}$ of the $1 \mathrm{X}$ - PBS was then transferred into a black plate and the free 7-amino4-methylcoumarin (AMC) liberated was measured fluorimetrically in a multi-mode reader [Spectra Max M5] at excitation $(380 \mathrm{~nm})$ and emission $(460 \mathrm{~nm})$. The results are displayed as mean $(+/-$ standard error) and are expressed as a percentage of the control, which was considered to be $100 \%$. All samples were assayed in triplicate in three independent experiments.
Inhibition of $26 \mathrm{~S}$ proteasome activity in cell extracts MCF-7 or MDA-MB-231 cells $\left(1 \times 10^{7}\right)$ were harvested, washed twice in 1X-PBS and re-suspended in $1 \mathrm{ml} \mathrm{ATP/}$ DTT lysis buffer $[10 \mathrm{mmol} / \mathrm{L}$ Tris- $\mathrm{HCl}(\mathrm{pH} 7.8), 5 \mathrm{mmol} /$ L ATP, $0.5 \mathrm{mmol} / \mathrm{l} \mathrm{DTT,} 5 \mathrm{mmol} / \mathrm{L} \mathrm{MgCl}_{2}$ ]. Cells were incubated on ice for 10 minutes, followed by sonication for 15 seconds. The lysate was centrifuged at $2000 \mathrm{rpm}$ for 10 minutes at $4^{\circ} \mathrm{C}$. The supernatant enriched in $26 \mathrm{~S}$ proteasomes is the cell extract which was used for the assay. This was mixed with glycerol (20\% final concentration), aliquoted and stored at $-80^{\circ} \mathrm{C}$, and was stable for at least 1 month. The total protein content of the cell extract was estimated by the Bicinchoninic Acid (BCA) method using a kit (Bangalore Genei, Bangalore, India). The assay was carried out in a total of $200 \mu \mathrm{l}$ reaction volume containing proteasome extract (50 $\mu \mathrm{g}$ protein), $50 \mathrm{mM}$ EDTA, varying concentrations of the CLE/MG-132 and $50 \mu \mathrm{M}$ of the proteasomal fluorogenic substrates and incubated for $2 \mathrm{~h}$ at $37^{\circ} \mathrm{C}$. The amount of free 7-amino-4-methylcoumarin (AMC) liberated was measured fluorimetrically. The results are expressed as mean $(+/-$ standard error) as a percentage of the control, which was considered to be $100 \%$. All samples were assayed in triplicate in three independent experiments.

\section{Statistical analysis}

All experiments were performed in triplicates and repeated at least three times and the data are presented as mean $+/-$ SEM. Mean values were compared across concentrations of CLE using non-parametric test of Kruskal-Wallis one-way ANOVA for each cell line using the SPSS statistical software. Differences between groups were considered significant at $\alpha$ (probability) level of $</=0.05$.

\section{Results}

M. koenigii leaf extract alters viability and growth kinetics of breast cancer cells

The TPC of the methanolic extract of curry leaves was $3 \mu \mathrm{g}$ of GAEs/ $\mu$ l of the CLE. MTT assays were performed with different concentrations of CLE (GAE) in both the cell lines at the $12 \mathrm{~h}$ and $24 \mathrm{~h}$ time points to assess the effect of the extract on cell viability. There was a significant $(\mathrm{p}<0.05)$ time and dose-dependent decrease in cell viability in both the cell lines. As expected, the decrease in cell viability observed after $24 \mathrm{~h}$ of treatment was higher compared to $12 \mathrm{~h}$. In addition, MDA-MB-231 cells (Figure 1A and 1B) appeared to be more sensitive to CLE induced cell death than MCF-7 cells (Figure 1D and 1E). 24 h post treatment, a $50 \%$ reduction in cell viability was observed in MDA-MB231 and MCF-7 cells at $15 \mu \mathrm{g}$ and $37.5 \mu \mathrm{g}$ GAE of CLE respectively. As a positive control, the effect of MG-132- a specific inhibitor of the proteolytic activity of the $26 \mathrm{~S}$ proteasome was also assessed on cell viability in both the breast cancer cell lines. 24 h post treatment with MG-132, a 50\% 


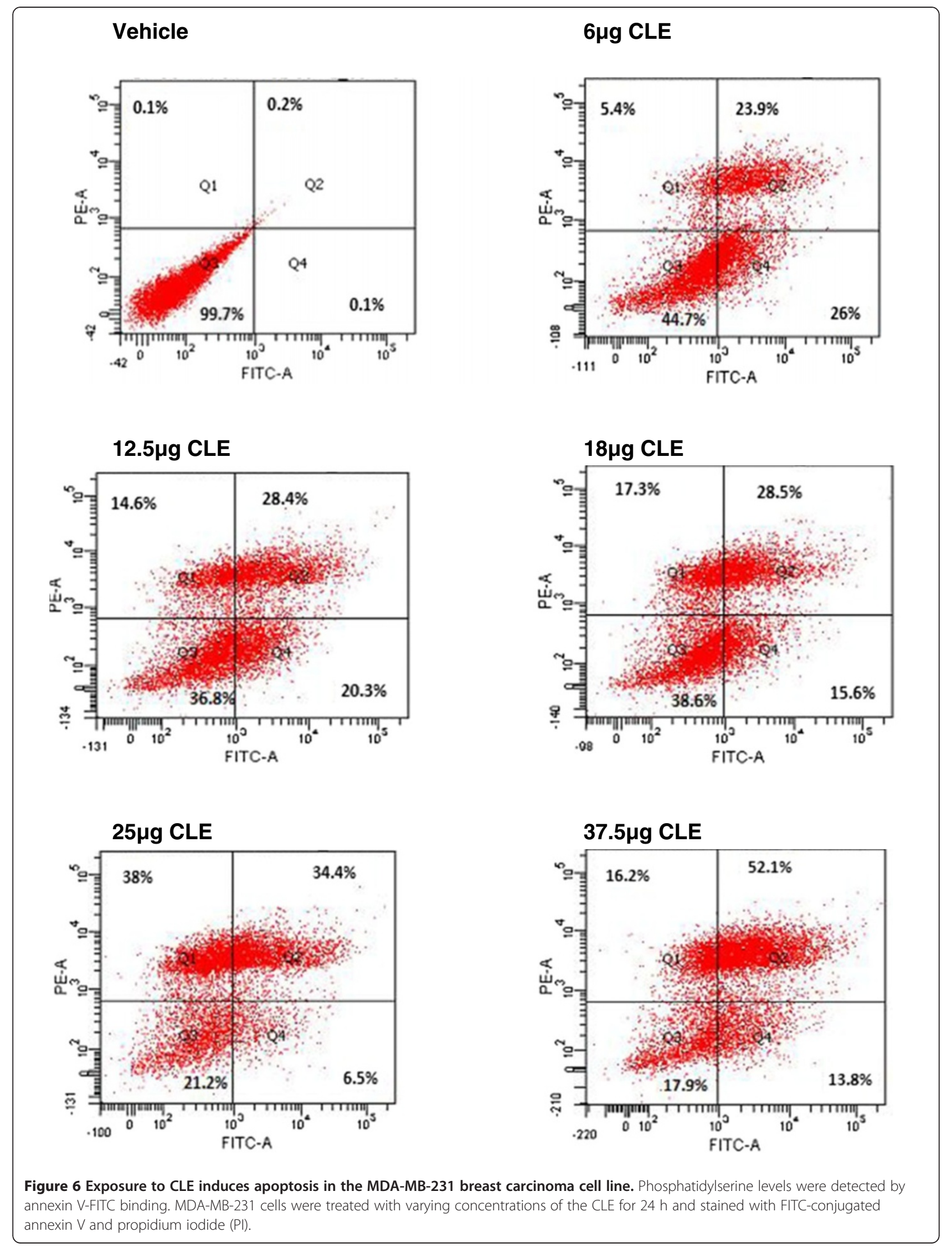




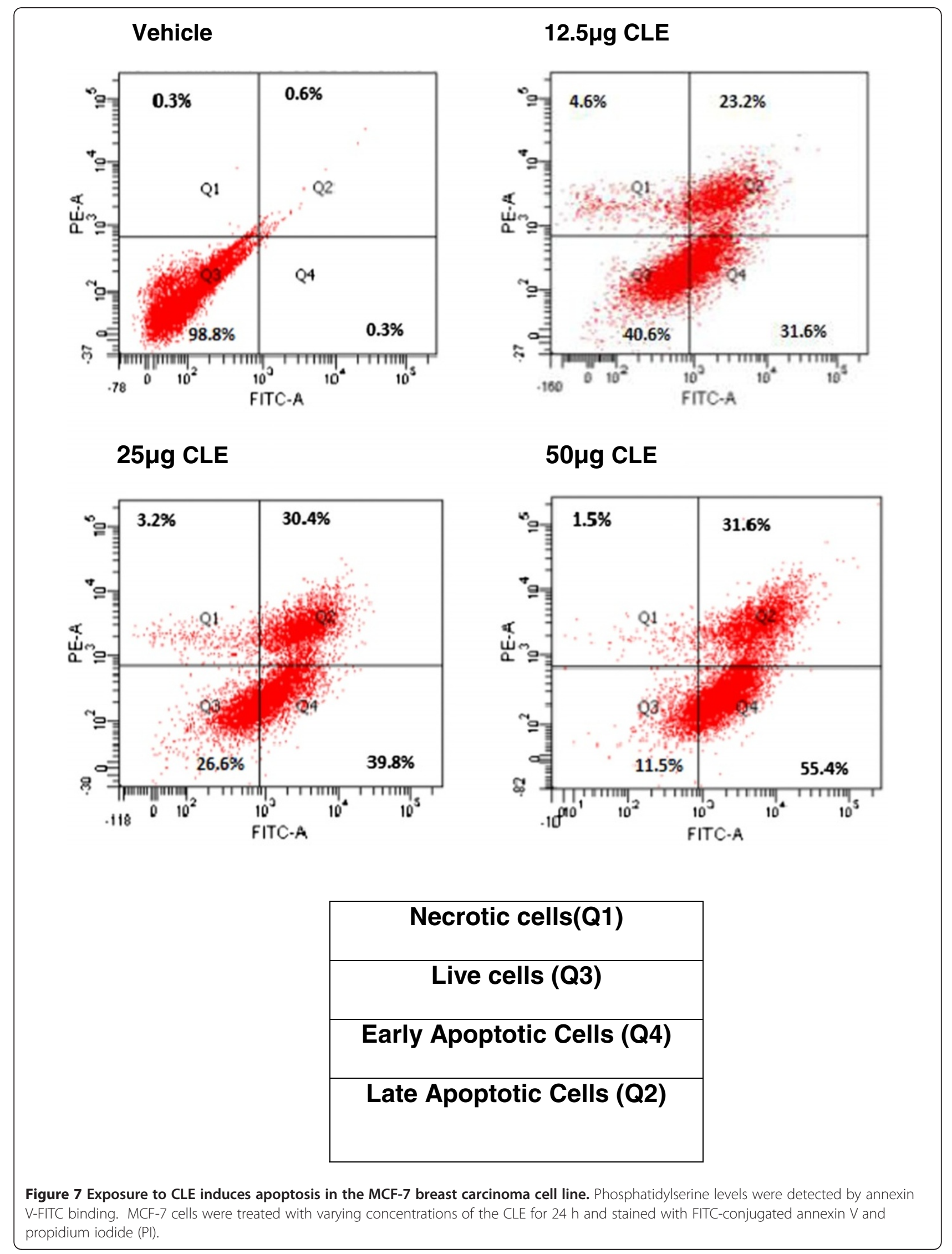




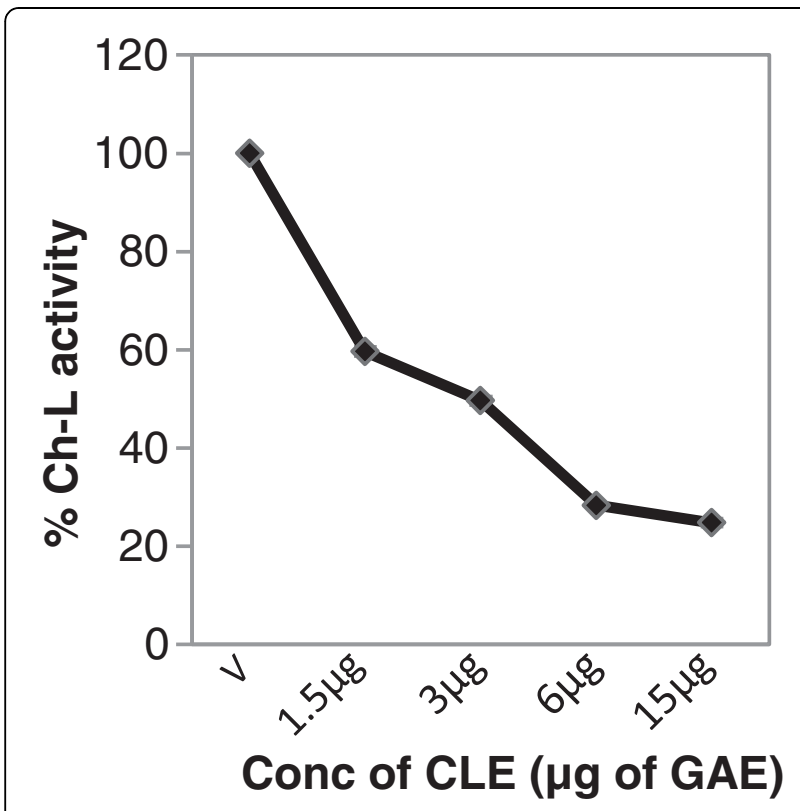

Figure 8 Curry leaf extract inhibits activity of purified $20 \mathrm{~S}$ proteasome. Purified 205 proteasome from rabbit was incubated with $40 \mu \mathrm{M}$ of fluorogenic peptide substrate for Ch-L activity in the presence of various concentrations of the CLE for $2 \mathrm{~h}$ at $37^{\circ} \mathrm{C}$. The fluorescence intensity of the free AMCs was determined using fluorescence mode in a multimode reader with excitation (380 nm) and emission $(460 \mathrm{~nm})$

reduction in cell viability was observed at $20 \mu \mathrm{M}$ and $>40 \mu \mathrm{M}$ of MG-132 in MDA-MB-231and MCF-7 cells respectively (Figure $1 \mathrm{C}$ and $1 \mathrm{~F}$ ).

To test the effect of CLE on growth kinetics, MCF-7 and MDA-MB-231 cells were seeded at a lower density and treated with different concentrations of the CLE. After incubation for a week, it was observed that at a dose of $25 \mu \mathrm{g}$ GAE of CLE, no colonies were found in either MDA-MB231 (Figure 2A) or MCF-7 cells (Figure 2B). In line with our observations on cell viability (MTT assay), MDA-MB231 cells appeared to be more sensitive than MCF-7 cells. This is supported by our findings where a lesser concentration of CLE was needed to inhibit the formation of colonies in MDA-MB-231 cells in comparison to MCF-7 cells.

\section{M. koenigii leaf extract induces growth arrest and apoptosis in breast cancer cells}

Cell cycle experiments were done to determine whether CLE treatment arrested growth in MDA-MB-231 and MCF-7 cells. In both the breast carcinoma cell lines CLE treatment showed a dose-dependent arrest in the $\mathrm{S}$ phase of the cell cycle resulting in complete inhibition of cell proliferation (Figures 3 and 4; Tables 1 and 2). That inhibition of cell proliferation denoted by G2-M phase was observed at $12.5 \mu \mathrm{g}$ GAE in MDA-MB-231 cells, whereas, in MCF-7 cells it was seen at $37.5 \mu \mathrm{g}$ GAE, corroborates the greater sensitivity of MDA-MB-231
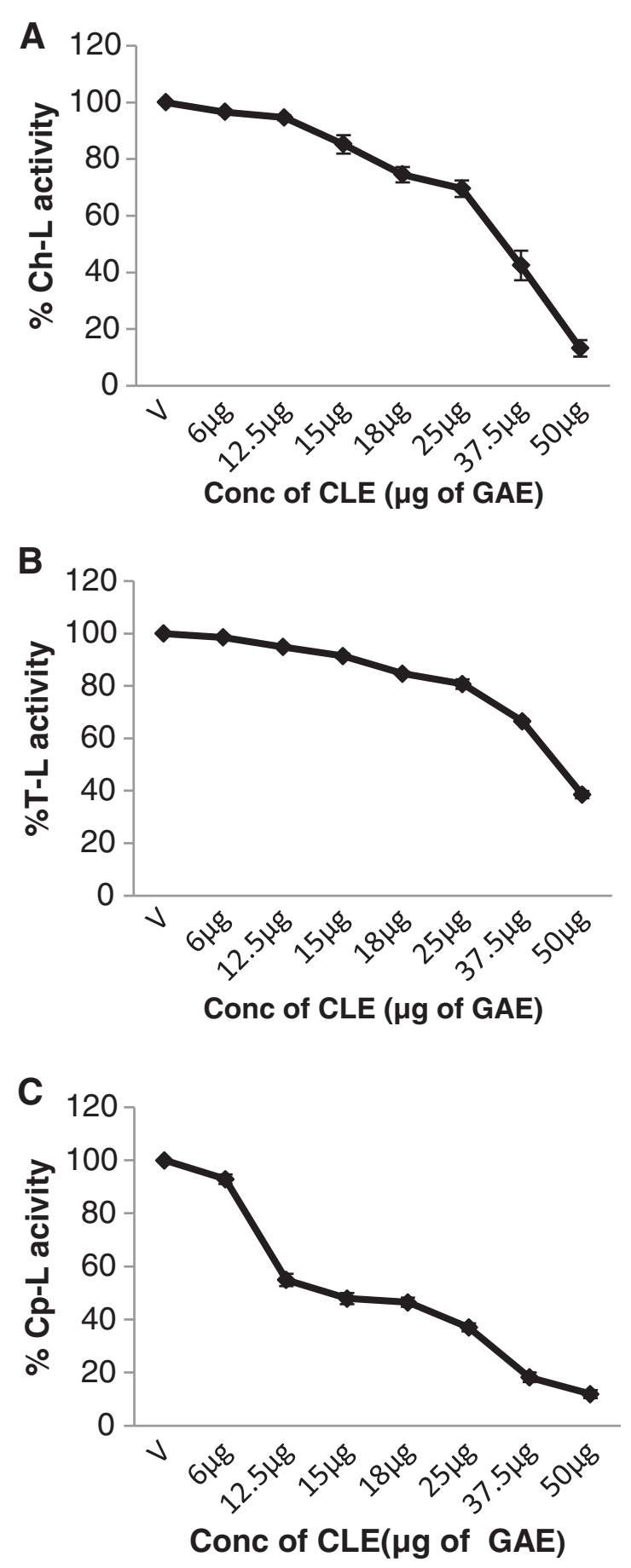

Figure 9 Inhibition of the enzymatic activities of the $26 \mathrm{~S}$ proteasome by the CLE in intact MDA-MB-231 breast cancer cell line. Intact MDA-MB-231 were treated for $24 \mathrm{~h}$ with or without the CLE followed by $2 \mathrm{~h}$ incubation at $37^{\circ} \mathrm{C}$ with the fluorogenic substrate for $\mathrm{Ch}-\mathrm{L}$ or $\mathrm{T}-\mathrm{L}$ or $\mathrm{Cp}-\mathrm{L}$ activities respectively. The fluorescent intensity of the free AMCs was determined in a multimode reader with excitation $(380 \mathrm{~nm})$ and emission $(460 \mathrm{~nm})$. Each activity was expressed as the percentage of the control (defined as 100\%). Panel A, B \& C represents Ch-L, T-L and Cp-L activities respectively. 
than MCF-7 cells to the CLE induced effects. Interestingly, CLE had no effect on cell cycle in the normal WI-38 cell line at any of the concentrations tested (Figure 5 and Table 3), indicating that CLE could arrest growth only in cancer but not normal cells.

Further, Annexin-V binding experiments were conducted in both cell lines to determine the probable mechanism of cell death. That $6 \mu \mathrm{g}$ CLE resulted in $45 \%$ of live MDA-MB231 cells whereas, a dose of $12.5 \mu \mathrm{g}$ CLE was required for a similar effect in MCF-7 cells not only confirms the greater sensitivity of MDA-MB-231 than MCF-7 cells but also suggests apoptosis to be the probable mechanism of cell death. This is confirmed by our finding that CLE demonstrated a dose dependent increase in the $\%$ of apoptotic cells in both MDA-MB-231 and MCF-7 cells. 50\% of cells were apoptotic with $6 \mu \mathrm{g}$ CLE in MDA-MB-231 cell line and it increased to $66 \%$ at a dose of $37.5 \mu \mathrm{g}$ CLE (Figure 6). A similar dose dependent increase in the \% apoptotic cells was seen in MCF-7 cells (Figure 7).

\section{M. koenigii leaf extract inhibits 20 S purified proteasome activity}

We then tested whether or not CLE inhibited the activity of the purified 20S rabbit proteasome in a cell-free system. Indeed CLE decreased the chymotrypsin-like activity of the $20 \mathrm{~S}$ proteasome in a dose-dependent manner and a
$50 \%$ decrease $\left(\mathbf{I C}_{\mathbf{5 0}}\right)$ in activity was seen at a concentration of CLE equivalent to $3 \mathrm{ug}$ of Gallic Acid (GAE)/ $\mu \mathrm{l}$ of the extract (Figure 8).

\section{M. koenigii leaf extract inhibits cellular 26S proteasome activity in intact cells}

Whether the CLE also inhibited the activity of the 26S proteasome in living cancer cells was assessed next in both MCF-7 and MDA-MB-231 cells. Similar to its effects on the purified $20 \mathrm{~S}$ rabbit proteasome, CLE showed a significant $(\mathrm{p}<0.05)$, dose-dependent decrease in the chymotrypsin-like, trypsin-like and caspase-like activities of the $26 \mathrm{~S}$ proteasome in intact cancer cells (Figures 9 and 10).

On the other hand, CLE did not inhibit the chymotrypsin-like activity of the $26 \mathrm{~S}$ proteasome at any of the concentrations tested in the normal WI38 cells (Figure 10D) indicating the specificity of the effect to cancer cells.

\section{M. koenigii leaf extract inhibits cellular $26 \mathrm{~S}$ proteasome activity in cell extracts}

Further to confirm that the CLE inhibits the $26 \mathrm{~S}$ proteasome, cell extracts enriched in $26 \mathrm{~S}$ proteasomes were prepared from both MCF-7 and MDA-MB-231 cells. The cell extracts were then treated with the CLE and

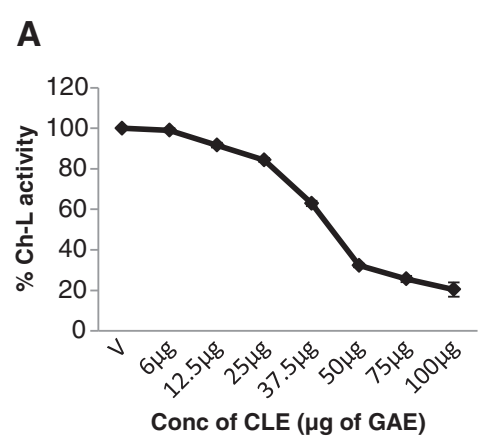

\section{B}

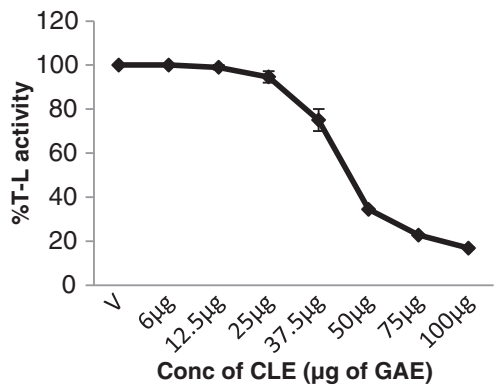

C

D
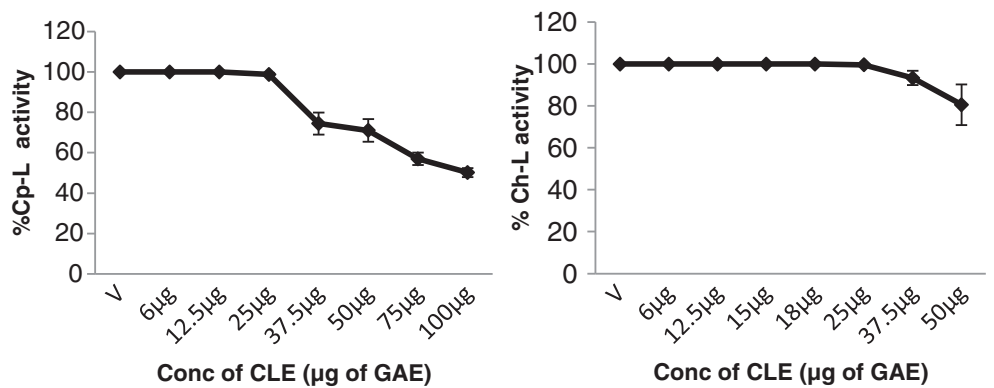

Figure 10 Inhibition of the enzymatic activities of the $26 \mathrm{~S}$ proteasome by the CLE in intact MCF- 7 breast cancer cell line and WI-38 normal cell line. Intact MCF-7 or WI-38 cells were treated for $24 \mathrm{~h}$ with or without the CLE followed by $2 \mathrm{~h}$ incubation at $37^{\circ} \mathrm{C}$ with the fluorogenic substrate for either Ch- $L$ or T-L or Cp-L activities respectively. The fluorescent intensity of the free AMCs was determined in a multimode reader with excitation $(380 \mathrm{~nm})$ and emission $(460 \mathrm{~nm})$. Each activity was expressed as the percentage of the control (defined as 100\%). Panel $\mathbf{D}$ depicts results from WI-38 cells. Panels A \& D represents Ch- $L$ activity; panels $\mathbf{B} \& \mathbf{C}$ depicts T-L and Cp-L activities respectively. 

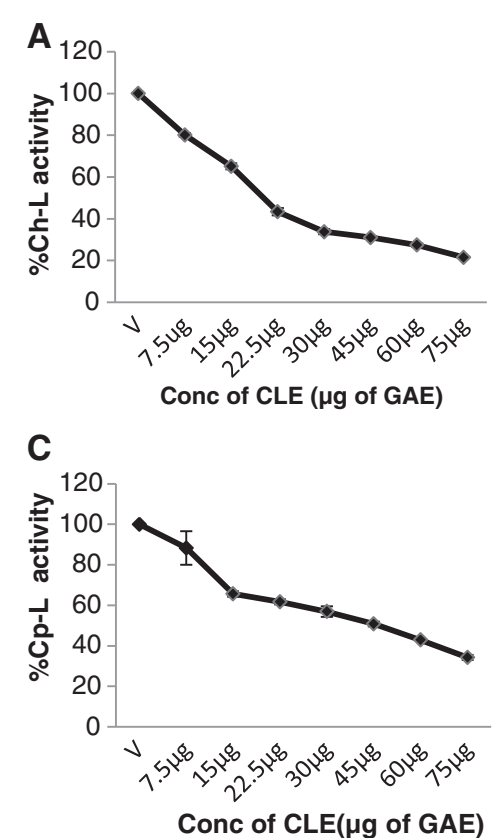

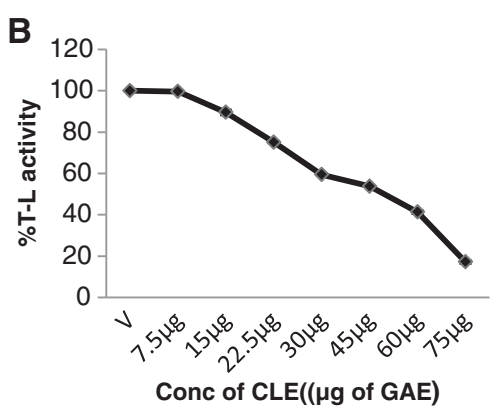

D

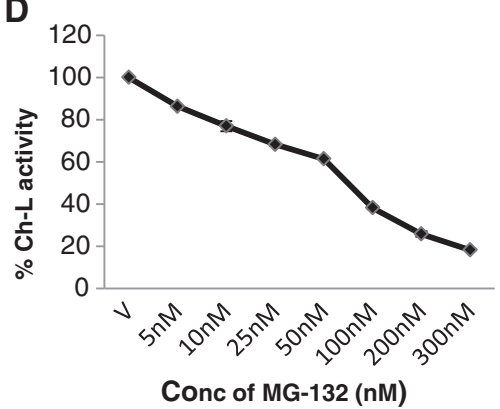

Figure 11 Concentration-dependent inhibition of the enzymatic activities of the 265 proteasome by the CLE or MG-132 in MDA-MB231 cell extracts. Cell extracts ( $=50 \mu \mathrm{g}$ protein) were incubated with $50 \mu \mathrm{M}$ of the fluorogenic substrates specific for $C h-L, T-L$ and $C p-L$ activities in the presence of various concentrations of the CLE for $2 \mathrm{~h}$ at $37^{\circ} \mathrm{C}$. Each activity was expressed as the percentage of the control (defined as 100\%). Panel A, B \& C depicts Ch-L, T-L and Cp-L activities respectively, whereas panel $\mathbf{D}$ depict Ch- $L$ activity with the synthetic proteasome inhibitor MG-132.

inhibition of the three proteasomal activities was assessed. It was interesting that CLE inhibited the chymotrypsinlike, trypsin-like and caspase-like activities of the $26 \mathrm{~S}$ proteasome in cell extracts in a dose-dependent manner in both MDA-MB-231 [ $\mathrm{IC}_{50}$ of $22.5 \mu \mathrm{g}$ CLE] and MCF-7 cells [ $\mathrm{IC}_{50}$ of $30 \mu \mathrm{g}$ CLE] (Figures 11 and 12). As a positive control MG-132, a proteasome inhibitor was also tested. It was observed that MG-132 decreased the chymotrypsinlike activity of the $26 \mathrm{~S}$ proteasome in a dose-dependent manner in cell extracts prepared from both MDA-MB231 and MCF-7 cells with an $\mathrm{IC}_{50}$ of $>50 \mathrm{nM}$ and $25 \mathrm{nM}$ in the two cell lines respectively (Figures 11D \& 12C).

\section{Discussion}

Search for new anti-cancer drugs from natural sources is one of the most important approaches for cancer prevention and treatment. In recent years, more emphasis is laid on Complementary and Alternative [CAM] forms of medicine for the treatment of various cancers, among which herbal medicine is now being explored for cancer therapy [36]. Dietary constituents have chemopreventive and chemotherapeutic potential, in addition to ameliorating the side effects associated with conventional chemotherapy. In this context, a recent approach in cancer therapy advocates the inhibition of the proteolytic activity of $26 \mathrm{~S}$ proteasome, the multi-enzymatic protease complex in cells. Unlike normal cells, cancer cells have increased proteasomal activity which is essential for their survival and uninhibited proliferation [37-39]. Inhibition of the proteasome results in apoptosis and cancer cell death [40]. Importantly, inhibitors of the $20 \mathrm{~S}$ proteolytic unit of the proteasome have been shown to induce apoptosis and cell cycle arrest only in neoplastic cells but not in normal cells [39-41]. Therefore, the proteasome has emerged as an attractive molecular target for cancer therapy [42]. A number of synthetic proteasome inhibitors have been described and most of them interfere with the proteolytic activity of the $\beta$ subunits of the $20 \mathrm{~S}$ proteasome. These inhibitors which bind the active site either reversibly or irreversibly include peptide aldehydes such as MG-132, non-peptide inhibitors such as lactacystin and epoxomycin and peptide boronates such as bortezomib [43].

Bortezomib/Velcade/PS-341 is the first-in-line and the only dipeptide boronate proteasome inhibitor to be approved by the FDA in 2003 for the treatment of patients with refractory multiple myeloma. Bortezomib is now being tested in a variety of hematological and solid tumors including non-Hodgkin's lymphoma, prostate, breast and non-small-cell-lung cancer $[44,45]$. In recent years, synthetic polyphenols such as apigenin, epigallocatechin gallate [EGCG], quercitin and myrcetin have been reported to act as proteasome inhibitors and induce cell death in cancer cells [24]. 

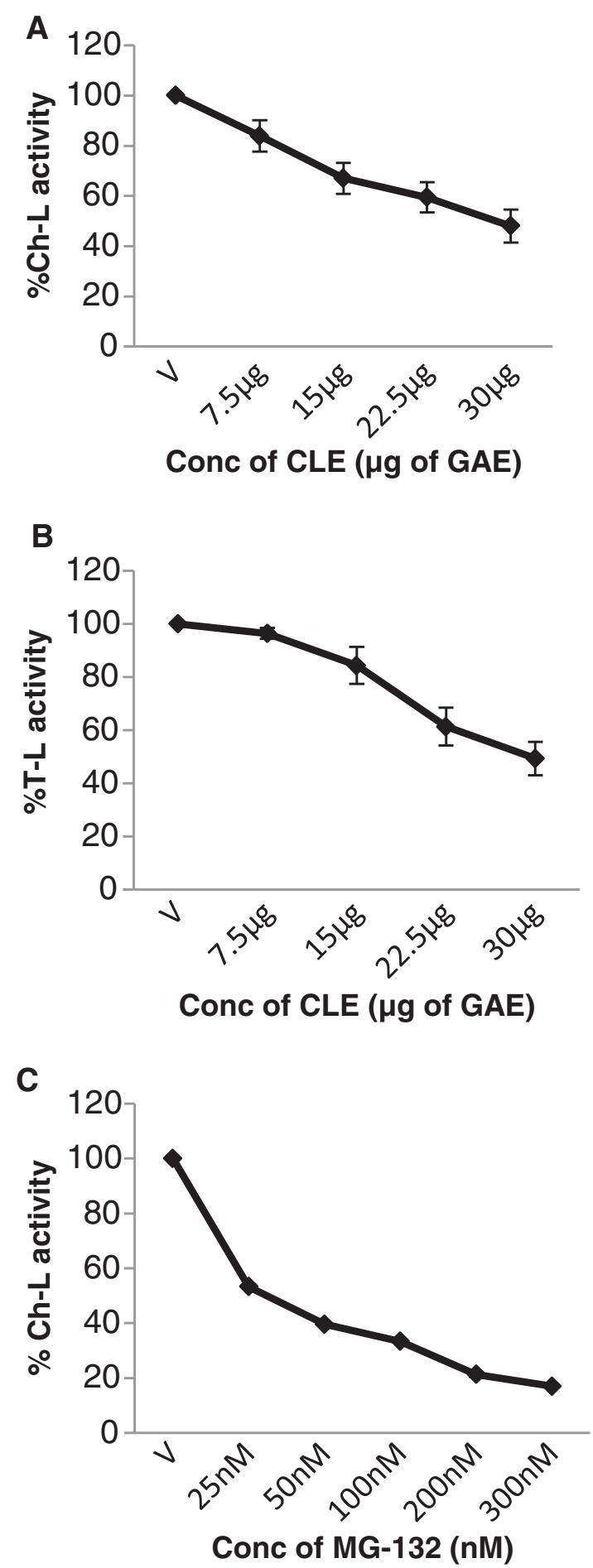

Figure 12 Concentration-dependent inhibition of the enzymatic activities of the $26 \mathrm{~S}$ proteasome by the CLE or MG-132 in MCF-7 cell extracts. Cell extracts ( $=50 \mu \mathrm{g}$ protein) were incubated with $50 \mu \mathrm{M}$ of the fluorogenic substrates specific for Ch-L, T-L and Cp-L activities in the presence of various concentrations of the CLE for $2 \mathrm{~h}$ at $37^{\circ} \mathrm{C}$. Each activity was expressed as the percentage of the control (defined as 100\%). Panel A \& B depicts Ch-L and T-L activities respectively, whereas panel $\mathbf{C}$ depicts Ch-L activity with MG-132.
Drug resistance limits the effectiveness of existing treatment options and is a major challenge faced in current cancer research. Interestingly, it has been shown that lactacystin and bortezomib enhance sensitivity of cancer cells that are resistant to routine chemotherapy [46,47]. Nevertheless, synthetic proteasome inhibitors are associated with some toxicity. Therefore, proteasome inhibitors from natural food sources with minimal or no toxicity can be potential anticancer agents.

In the present study, we report the anticancer potential of M. koenigii leaf extracts in two human breast carcinoma cell lines. In recent years, dietary polyphenols have attracted lot of attention owing to their anti-tumor activities $[48,49]$. One such activity is the inhibition of the proteasome in cancer cells leading to cell death. Recent work from our laboratory [21] has demonstrated that M. koenigii leaf extract is a rich source of polyphenols. In this study, we found that a hydro-methanolic extract of curry leaves is rich in polyphenol content. Extracts of M. koenigii leaves have been reported to possess various biological activities such as anti-diabetic, anti-oxidative and anti-inflammatory [8-10]. Recently, carbazole alkaloids from M. koenigii have shown anti-cancer activity in leukemia cells [18-20]. However, the underlying mechanism(s) are not reported yet. In the present work, we demonstrate for the first time that the hydro-methanolic extract of curry leaf has proteasome-inhibitory potential and induces cell death in human breast cancer cells.

We found that the methanolic extract of curry leaves significantly decreased cell viability and proliferation of both MCF-7 and MDA-MB-231 breast cancer cells in a dose-dependent manner. This was further supported by the significant reduction in the number of colonies in CLE treated cells compared to vehicle treated cells. Our cell viability and colony formation data shows that CLE altered the growth kinetics of both MCF-7 and MDAMB-231 cells. Therefore, curry leaves appear to be a promising drug candidate for restricting the growth of breast cancer cells.

In order to assess the stage at which the cell growth was arrested by CLE, we performed cell cycle experiments and observed that there was a clear arrest of cells in the synthetic or $\mathrm{S}$ phase. In contrast to its effect on the breast carcinoma cell lines, CLE interestingly, had no effect on the different phases of the cell cycle in the normal fibroblast cell line. Anti-cancer drugs can result either in programmed cell death/apoptosis or necrosis. In order to identify the probable cell death pathway involved, we used Annexin V binding to test if the cell death occurred through apoptosis or necrosis. Indeed it was found that in both the breast cancer cell lines CLE induced apoptotic cell death.

We tested next, whether the anti-cancerous effect of the CLE was due its potential of inhibiting the proteolytic 
activity of the protein degrading machine present in eukaryotic cells - the $26 \mathrm{~S}$ proteasome, which is now considered to be a novel approach for cancer therapy. We observed that CLE inhibited the purified 20S proteasome enzyme. Furthermore, it significantly inhibited all the three enzymatic activities associated with the $26 \mathrm{~S}$ proteasome in living cells in a dose-dependent manner. To further confirm the findings in live cells, cell extracts were prepared from both breast cancer cells and tested for the potential of the CLE in inhibiting the cellular proteasome. Similar to our findings in intact cells we found that CLE inhibited the $26 \mathrm{~S}$ proteasome in cell extracts also in a dose-dependent manner. To test whether or not the inhibitory effect of the CLE on the proteasome activity was specific to cancer cells, we tested its effects in WI-38, a normal lung fibroblast cell line. Interestingly, CLE had no effect on the chymotrypsin-like activity of the $26 \mathrm{~S}$ proteasome in live WI-38 cells. Hence, data from our proteasome-inhibition experiments suggests that the CLE could inhibit the cellular proteasome leading to cell death in cancer cells but not normal cells. Our data is in accordance with earlier reports that proteasome inhibitors selectively inhibited proteasome activity only in neoplastic cells $[39,50,51]$.

\section{Conclusion}

Our results indicate that the hydro-methanolic extract of curry leaves is a good source of active compound(s) that can potentially inhibit the $26 \mathrm{~S}$ proteasome specifically in cancer cells. The inhibition of the proteasome in cancer cells appears to be one of the important biological activities in M. koenigii leaves that can be exploited for cancer treatment. Hence, isolation and characterization of active component(s) from methanolic extracts of curry leaves could lead to the discovery of novel anticancer agents.

\begin{abstract}
Abbreviations
(MTT): 3-(4,5-dimethylthiazol-2-yl)-2,5-di-phenyltetrazolium bromide; (GAE): Gallic Acid Equivalents; (CLE): Curry leaf extract; (AMC): 7-amino-4methylcoumarin; (DMSO): Dimethyl sulphoxide; (EGCG): Epigallocatechin gallate; (DTT): Dithiothretol; (FITC): Fluorescein isothiocyanate;

(PBS): Phosphate buffered saline.
\end{abstract}

\section{Competing interests}

The authors declare that they have no competing interests.

\section{Authors' contributions}

AYI designed the study and wrote the manuscript. BN carried out most of the experiments. RA assisted with the cell cycle and Annexin-V experiments and data analysis. AC helped with cytotoxicity assays. BKN has done the statistical analysis of the data. RM has critically read and revised the manuscript for intellectual content. All authors read and approved the final manuscript.

\section{Acknowledgements}

This work was funded by a grant from the Department of Biotechnology, India (Project No: BR/PR/11128/FNS/20/403/2008) to AYI. We thank the University Grants Commission for providing fellowship to BN. We thank our Director Dr. B. Sesikeran for the valuable support and encouragement during the course of the studies. We thank Ms. GV Asha for the assistance provided in estimation of the phenolic content of the CLES.

\section{Author details}

'Department of Endocrinology \& Metabolism, National Institute of Nutrition, Hyderabad, India. ${ }^{2}$ Department of Stem Cell Research, National Institute of Nutrition, Hyderabad, India. ${ }^{3}$ Department of Statistics, National Institute of Nutrition, Hyderabad, India.

Received: 26 July 2012 Accepted: 4 January 2013

Published: 9 January 2013

\section{References}

1. Parkin DM, Bray F, Ferlay J, Pisani P: Estimating the world cancer burden: Globocan. Int J Cancer 2000, 94:153-156.

2. Pruthi JS: Spices and condiments. New Delhi: National Book Trust India; 1976.

3. Chevallier A: The encyclopedia of medicinal plants. London: Dorlon Kindersley Publisher; 1996.

4. Sivarajan W, Balachandran I: Ayurvedic drugs and their plant sources. New Delhi: Oxford \& IBH Publishing; 1994.

5. Muthumani P, Venkatraman S, Ramseshu KV, Meera R, Devi P, Kameswari B: Pharmacological studies of anticancer, anti inflammatory activities of Murraya koenigii (Linn) Spreng in experimental animals. J Pharm Sci Res 2009, 1:137-141.

6. Nayak A, Banerji J, Banerji A, Mandal S: Review on chemistry and pharmacology of Murraya koenigii Spreng (Rutaceae). J Chem Pharm Res 2010, 2:286-299.

7. Kesari AN, Kesari S, Singh SK, Gupta RK, Watal G: Studies on the glycemic and lipidemic effect of Murraya koenigii in experimental animals. J Ethnopharmacol 2007, 112(2):305-311.

8. Arulselvan P, Senthilkumar GP, Sathish Kumar D, Subramanian S: Antidiabetic effect of Murraya koenigii leaves on streptozotocin induced diabetic rats. Pharmazie 2006, 61(10):874-877.

9. Lawal HA, Atiku MK, Khelpai DG: Hypoglycaemic and hypolipidemic effect of aqueous leaf extract of Murraya koenigii in normal and alloxandiabetic rats. Niger J Physiol Sci 2008, 23(1-2):37-40.

10. Gupta S, Prakash J: Studies on Indian green leafy vegetables for their antioxidant activity. Plant Foods Hum Nutr 2009, 64(1):39-45.

11. Tachibana Y, Kikuzaki H, Lajis NH, Nakatani N: Antioxidative activity of carbazoles from Murraya koenigii leaves. J Agric Food Chem 2001, 49(11):5589-5594.

12. Khan BA, Abraham A, Leelamma S: Anti-oxidant effects of curry leaf, Murraya koenigii and mustard seeds, Brassica juncea in rats fed with high fat diet. Indian J Exp Biol 1997, 35(2):148-150.

13. Adebajo AC, Ayoola OF, Iwalewa EO, Akindahunsi AA, Omisore NO, Adewunmi CO, Adenowo TK: Anti-trichomonal, biochemical and toxicological activities of methanolic extract and some carbazole alkaloids isolated from the leaves of Murraya koenigii growing in Nigeria. Phytomedicine 2006, 13(4):246-254.

14. Mandal S, Nayak A, Kar M, Banerjee SK, Das A, Upadhyay SN, Singh RK, Banerji A, Banerji J: Antidiarrheal activity of carbazole alkaloids from Murraya koenigii Spreng (Rutaceae) seeds. Fitoterapia 2010, 81(1):72-74.

15. Xie JT, Chang WT, Wang CZ, Mehendale SR, Li J, Ambihaipahar R, Ambihaipahar U, Fong HH, Yuan CS: Curry leaf (Murraya koenigii Spreng.) reduces blood cholesterol and glucose levels in ob/ob mice. Am J Chin Med 2006, 34(2):279-284.

16. Gupta S, George M, Singhal M, Sharma GN, Garg V: Leaves extract of murraya koenigii linn for anti-inflammatory and analgesic activity in animal models. J Adv Pharm Technol Res 2010, 1(1):68-77.

17. Shah AS, Wakade AS, Juvekar AR: Immunomodulatory activity of methanolic extract of Murraya koenigii (L) Spreng. Leaves. Indian J Exp Biol 2008, 46(7):505-509.

18. Ito C, Itoigawa M, Nakao K, Murata T, Tsuboi M, Kaneda N, Furukawa H: Induction of apoptosis by carbazole alkaloids isolated from Murraya koenigii. Phytomedicine 2006, 13(5):359-365.

19. Roy MK, Thalang VN, Trakoontivakorn G, Nakahara K: Mechanism of mahanine-induced apoptosis in human leukemia cells (HL-60). Biochem Pharmacol 2004, 67(1):41-51.

20. Bhattacharya K, Samanta SK, Tripathi R, Mallick A, Chandra S, Pal BC, Shaha $C$, Mandal C: Apoptotic effects of mahanine on human leukemic cells are mediated through crosstalk between Apo-1/Fas signaling and the Bid 
protein and via mitochondrial pathways. Biochem Pharmacol 2010, 79(3):361-372.

21. Ayesha I, Bindu N, Shulagna S, Chandana M, Mehrajuddin B, Raghunath M: Proteasome inhibitory potential of commonly consumed dietary ingredients. Int J Food Nutr Sci 2012, 1(4):27-31.

22. Scalbert A, Manach C, Morand C, Rémésy C, Jiménez L: Dietary polyphenols and the prevention of diseases. Crit Rev Food Sci Nutr 2005, 45(4):287-306. Review.

23. Scalbert A, Johnson IT, Saltmarsh M: Polyphenols: antioxidants and beyond. Am J Clin Nutr 2005, 81(Suppl 1):215S-217S. Review.

24. Chen D, Daniel KG, Chen MS, Kuhn DJ, Landis-Piwowar KR, Dou QP: Dietary flavonoids as proteasome inhibitors and apoptosis inducers in human leukemia cells. Biochem Pharmacol 2005, 69(10):1421-1432

25. Pettinari A, Amici M, Cuccioloni M, Angeletti M, Fioretti E, Eleuteri AM: Effect of polyphenolic compounds on the proteolytic activities of constitutive and immuno-proteasomes. Antioxid Redox Signal 2006, 8(1-2):121-129.

26. Hershko A, Ciechanover A: The ubiquitin system. Annu Rev Biochem 1998, 67:425-479. Review.

27. Groll M, Ditzel L, Lowe J, Stock D, Bochtler M, Bartunik HD, Huber R: Structure of $20 \mathrm{~S}$ proteasome from yeast at 2.4 A resolution. Nature 1997 386:463-471.

28. Rivett AJ: The multicatalytic proteinase. Multiple proteolytic activities. J Biol Chem 1989, 264(21):12215-12219.

29. Jung T, Bader N, Grune T: Oxidized proteins: intracellular distribution and recognition by the proteasome. Arch Biochem Biophys 2007, 462(2):231-237. Review.

30. Tambyrajah WS, Bowler LD, Medina-Palazon C, Sinclair AJ: Cell cycledependent caspase-like activity that cleaves p27(KIP1) is the beta(1) subunit of the 20 S proteasome. Arch Biochem Biophys 2007, 466(2):186-193.

31. Chen WJ, Lin JK: Induction of G1 arrest and apoptosis in human jurkat T cells by pentagalloylglucose through inhibiting proteasome activity and elevating p27Kip1, p21Cip1/WAF1, and Bax proteins. J Biol Chem 2004, 279(14):13496-13505.

32. Hilt W, Wolf DH: Proteasomes: The World of Regulatory Proteolysis. Georgetown, Texas: Landes Bioscience; 2000.

33. Goldberg AL: Functions of the proteasome: the lysis at the end of the tunnel. Science 1995, 268(5210):522-523. Review.

34. Hochstrasser M: Ubiquitin, proteasomes, and the regulation of intracellular protein degradation. Curr Opin Cell Biol 1995, 7(2):215-223. Review.

35. Singleton VL, Orthofer R, Lamuela-Raventos RM: Analysis of total phenols and other oxidation substrates and antioxidants by means of FolinCiocalteu Reagent. Methods Enzymol 1999, 299:152-178.

36. Adams M, Jewell AP: The use of complementary and alternative medicine by cancer patients. Int Semin Surg Oncol 2007, 4:10.

37. Wada M, Kosaka M, Saito S, Sano T, Tanaka K, Ichihura A: Serum concentrations and localization in tumor cells of proteasomes in patients with hematologic malignancy and their pathophysiologic significance. J Lab Clin Med 1993, 121:215-223.

38. Li B, Dou QP: Bax degradation by the ubiquitin/proteasome-dependent pathway: involvement in tumor survival and progression. Proc Natl Acad Sci USA 2000, 97(8):3850-3855.

39. An B, Goldfarb RH, Siman R, Dou QP: Novel dipeptidyl proteasome inhibitors overcome $\mathrm{Bcl}-2$ protective function and selectively accumulate the cyclin-dependent kinase inhibitor p27 and induce apoptosis in transformed, but not normal, human fibroblasts. Cell Death Differ 1998 5(12):1062-1075.

40. Dou QP, Li B: Proteasome inhibitors as potential novel anticancer agents. Drug Resist Update 1999, 2(4):215-223.

41. Kazi A, Urbizu DA, Kuhn DJ, Acebo AL, Jackson ER, Greenfelder GP, Kumar NB, Dou QP: A natural musaceas plant extract inhibits proteasome activity and induces apoptosis selectively in human tumor and transformed, but not normal and non-transformed, cells. Int J Mol Med 2003, 12(6):879-887.

42. Landis-Piwowar KR, Milacic V, Chen D, Yang H, Zhao Y, Chan TH, Yan B, Dou QP: The proteasome as a potential target for novel anticancer drugs and chemosensitizers. Drug Resist Update 2006, 9(6):263-273. Review.

43. Adams J: The proteasome: structure, function, and role in the cell. Cancer Treat Rev 2003, 29(Suppl 1):3-9. Review.
44. Richardson PG, Hideshima T, Anderson KC: Bortezomib (PS-341): a novel, first-in-class proteasome inhibitor for the treatment of multiple myeloma and other cancers. Cancer Control 2003, 10(5):361-369. Review.

45. Richardson PG, Anderson KC: Bortezomib: a novel therapy approved for multiple myeloma. Clin Adv Hematol Oncol 2003, 1(10):596-600. Review.

46. Delic J, Masdehors P, Omura S, Cosset JM, Dumont J, Binet JL, Magdelénat $\mathrm{H}$ : The proteasome inhibitor lactacystin induces apoptosis and sensitizes chemo- and radio resistant human chronic lymphocytic leukemia lymphocytes to TNF-alpha-initiated apoptosis. Br J Cancer 1998, 77(7):1103-1107.

47. Ma MH, Yang HH, Parker K, Manyak S, Friedman JM, Altamirano C, Wu ZQ, Borad MJ, Frantzen M, Roussos E, Neeser J, Mikail A, Adams J, Sjak-Shie N, Vescio RA, Berenson JR: The proteasome inhibitor PS-341 markedly enhances sensitivity of multiple myeloma tumor cells to chemotherapeutic agents. Clin Cancer Res 2003, 9(3):1136-1144.

48. Kandaswami C, Lee LT, Lee PP, Hwang JJ, Ke FC, Huang YT, Lee MT: The antitumor activities of flavonoids. In Vivo 2005, 19:895-909.

49. Thomasset SC, Berry DP, Garcea G, Marczylo T, Steward WP, Gescher J: Dietary polyphenolic phytochemicals - promising cancer chemopreventive agents in humans? A review of their clinical properties. Int J Cancer 2007, 120:451-458.

50. Nam S, Smith DM, Dou QP: Ester bond-containing tea polyphenols potently inhibit proteasome activity in vitro and in vivo. $J$ Biol Chem 2001, 276(16):13322-13330.

51. Kuhn DJ, Lam WH, Kazi A, Daniel KG, Sung S, Chow LMC, Chan TH, Dou QP: Synthetic peracetate tea polyphenols as potent proteasome inhibitors and apoptosis inducers in human cancer cells. Front Bio 2005, 10:1010-1023.

doi:10.1186/1472-6882-13-7

Cite this article as: Noolu et al:: Murraya koenigii leaf extract inhibits proteasome activity and induces cell death in breast cancer cells. BMC Complementary and Alternative Medicine 2013 13:7.

\section{Submit your next manuscript to BioMed Central and take full advantage of:}

- Convenient online submission

- Thorough peer review

- No space constraints or color figure charges

- Immediate publication on acceptance

- Inclusion in PubMed, CAS, Scopus and Google Scholar

- Research which is freely available for redistribution 